\title{
The Impact of Advertising Credibility on Purchase Intentions: An Empirical Study among Iraqi Facebook Users
}

\author{
Raafat Awad Mosa
}

\section{ABSTRACT}

With the acceleration of the wave of technological developments, the advertising industry started to abandon its traditional tools adopted in addressing customers. The advertising landscape through social media networks has become the most visible way to communicate and interact with customers. However, the advertising messages launched by marketers on these networks do not receive an adequate response from the target customers. The credibility of the information provided by advertisements on social media networks platforms is still questionable by many customers. Which may reduce the effectiveness of these advertisements and undermine the efforts of marketers to generate sufficient conviction among customers to buy. Therefore, this study seeks to test the impact of advertising credibility on purchase intentions among Iraqi Facebook users. In order to achieve this goal, adopted a quantitative approach by surveying a sample of 487 respondents. The results showed that advertising credibility had a moderately positive effect on purchase intentions. The study recommended that marketers should be keen to provide realistic and honest information about marketing offers in their advertising messages.

Keywords: Advertising Credibility, Affirmation, Authenticity, Facebook, Purchase Intentions, Trust.

\section{INTRODUCTION}

Technological developments in the world have brought about wide changes in the advertising landscape, as digital communication technologies have topped the interests of marketers in delivering their voices to the largest possible number of customers [1]. Specifically, after the spread of the Internet as a popular communication tool among customers [2], as well as the creation of social media networks that enhanced rapprochement and communication among them [3], [4]. Despite the wide adoption of the Internet as an important source of information in various aspects of life, there are still difficulties that marketers face when using it as a means to attract the attention of customers and influence their purchase behavior [5]. In fact, many customers have described the Internet as a world with unclear horizons when purchase compared to the traditional purchase method that allows the customer to speak orally with the sales representative and directly check product specifications [6]. The unfavorable attitudes of customers towards online purchases are often due to their negative perceptions about the credibility of the information provided by online advertising content [7].

Nowadays, there is an expansion in the scope and amount of spending on online advertising [8]. The fierce competition as the dominant feature in the current business environment
Submitted : September 28, 2021

Published : October 26, 2021

ISSN: $2507-1076$

DOI: $10.24018 /$ ejbmr.2021.6.5.1123

Raafat Awad Mosa*

Department of Business Admin,

University of Basrah, College of Admin \&

Economics, Iraq.

(e-mail: raafat.musa ${ }^{\circledR}$ uobasrah.edu.iq)

*Corresponding Author has led marketers to believe that the best way to capture the customer's attention is through a massive and repetitive amount of advertising [9]. However, there is little interest by many customers in online advertising, and even a large percentage of these customers choose to hit the block button just by seeing an advertising [10]. Advertisements that adopt unreasonable or exaggerated descriptions of products or brands will certainly get a negative response and Customers will ignore it [11]. As a result, variables such as advertising credibility have become one of the important challenges facing online marketers, and perhaps the difficult obstacle to customer interaction with advertising and the formation of purchase intentions [12]. Credibility is the first step towards effective advertising [13]. Besides, advertising credibility is one of the critical variables and indicators in building customer attitudes towards the source and content of the advertisement [14], [15].

Undoubtedly, competition contributed to the prosperity of markets through the presence of various goods and services with different brands. When there is even the slightest doubt about the real advantages of the products displayed by the online advertisements, customers will inevitably hesitate to make a purchase or even develop an intent to purchase. Thus, in cases where the levels of confusion are high, advertisements are supposed to convey sufficient signals of credibility to customers [16]. Frequently, customers view advertising as an untrustworthy and unreliable source in 
making purchasing decisions, as it embodies the tactics of marketers through which they seek to increase sales and profits only [17]. Today, a large percentage of online advertising efforts are far from achieving their goals. As customers are becoming more aware of choosing useful content and interacting with marketing offers that respond better to their requirements than ever before [18]. Hence, there is a need to reconsider the assessment of the impact of online advertising on purchase intentions and customer behaviors [19]. In particular, the issue of the credibility of advertising on social networks [20]-[22].

Through a careful review of the previous literature, it can be inferred that there are few studies that dealt with the credibility of advertising, and most of these studies focused on credibility as a sub-dimensions of the effectiveness or value of advertising [14], [23]-[25]. Consequently, there emerges a knowledge gap about the motives or dimensions involved in advertising credibility [5], [26], [19]. Therefore, the current study seeks to enrich marketing knowledge by building a theoretical framework that shows the main motives/dimensions on which the measurement of advertising credibility depends, and then testing the impact of advertising credibility on purchase intentions among Iraqi customers who are users of the Facebook platform.

\section{LITERATURE REVIEW AND HYPOTHESIS DEVELOPMENT}

\section{A. Facebook}

Social media networks are a good example of the results of technological developments and the growing use of the Internet [27], [28]. These networks are a set of technologies that connect individuals and their friends who have specific interests and enable them to share information and materials over the Internet [29], [30]. Social media networks are incarnate in a number of platforms in which Facebook occupies a leading position [31], [32]. Facebook started as an educational platform for college students by Harvard student, Mark Zuckerberg in 2004 [33], [34]. Over time, Facebook has grown to become the most powerful platform in the world and the most attractive to users and marketers [35], [36]. From the point of view of its users, Facebook is a necessity similar to the need for air, water, and food [37], this platform represents the destination that attracts approximately 2.45 billion users worldwide [38]. Thus, Facebook provides a new place for advertising and opportunities to interact with customers and their requirements [39], [40]. This is what made Facebook occupy a prominent position in the interests of marketers as a point of contact that provides the shortest road to reach existing and target customers [41], [42].

\section{B. Advertising Credibility}

Advertising as a form of marketing communication represents that scene through which marketers seek to stimulate the desires of customers and persuade them to buy products and services [44]-[46]. The main goal of advertisers is to provide customers with the information they need to make purchasing decisions [47], [48]. The undeniable fact is that advertising cannot achieve the objectives set for it without the presence of credibility [13]. In general, credibility is a word that describes an individual's belief in the truth and honesty of information related to a particular aspect or issue
[9], [49]. The credibility in advertising literature means the extent of reassurance that customers show towards the truth and reasonableness of the advertising message [50]. More specifically, advertising credibility expresses "the degree to which the customer believes that statements made about the products in the advertisement are true and can be trusted"[51]. While [52] described the ad credibility as an expression of the level of customers' trust towards the integrity and realism of advertising messages sent by marketers, which ultimately determines the extent to which customers accept or reject the content of the advertisement based on their previous experiences.

\section{Purchase Intentions}

Purchasing intention is one of the variables that have been repeatedly studied in many marketing research [53], it is a necessary measure to understand customer behavior [54][56]. Not to mention that the purchasing intent is an effective tool for predicting the future buying trends of customers [57]. The term purchase intention refers to the motives that drive customers' preferences and tendencies to buy a brand or deal with a particular marketer [58], [59]. Simply, this term means the possibility for a customer to purchase a product as soon as [60]. Although the actual buying behavior has captured the interest of marketing researchers. Nevertheless, many studies have adopted purchase intention as an alternative variable in the study of actual purchase behavior, due the latter is difficult or impossible to measure in field studies. [61].

\section{Advertising Credibility Drivers $\backslash$ dimensions and Their Impact on Purchase Intentions}

When marketers seek to design advertisements that stimulates customers' purchase intentions, exaggeration can occur in many cases [62], but credibility is the guide that guides customers when they associate themselves with an advertisement, and then it is a prerequisite for the success of online marketing [16]. In this regard [10], [63] emphasized that ad credibility will determine the outlines of customers' perceptions and purchase intentions. Based on that, the first hypothesis is as follows:

\section{$\mathrm{H} 1$ : advertising credibility has a positive impact on purchase intentions among Facebook users.}

Advertising credibility drivers or dimensions can be determined in this study (trust, authenticity, and affirmation) [10], [64], [65].

\section{1) Trust}

In a marketing environment characterized by advertising chaos, showering customers with advertising messages has become a common strategy that marketer's resort to get into the customer's mind [66]. In fact, the effectiveness of advertising is not only achieved through spending money and frequency of appearances, but it is closely related to using the right formats to instill trust in the hearts of customers [67]. Trust is the main starting point for credibility, and it stems from honest and ethical business practices [64]. Trust in advertising describes the customer's perceptions of the truth of the information contained in the advertisement and the extent to which it affects his purchasing decisions [34]. Trust within advertising credibility drivers is a broad concept that reflects dimensions such as honesty, influence, and 
information reliability [68].

Managing trust amid high levels of customer skepticism is a critical factor in the success of online advertising campaigns [69], [70]. Naturally, low trust in ads on social networks, coupled with customers feeling that the marketer is unable to deliver on his promises will inevitably lead to reluctance to buy [71]. Trust in the online marketing channels has completely different dynamics than offline trust, as online trust gives alternative signals to the traditional buying process that involves touching the product and talking to salespeople, it is a critical factor to gain customer loyalty [72], [73]. The study [74] indicated that trust affects the purchasing behavior of customers on electronic platforms, especially Facebook. A study [75] reported that customers' trust in the advertising offered by stores on Facebook significantly influences their purchase intentions, this result is consistent with the results of studies [76], [77]. Therefore, the second hypothesis is:

\section{H1-1: Trust in advertising credibility has a positive impact on purchase intentions among Facebook users.}

\section{2) Authenticity}

Authenticity is not just a dimension or driver of ad credibility, but it is a basic requirement that marketing departments seek to achieve in various directions in response to what customers are looking for on an ongoing basis [78] [79]. Authenticity is one of the most important challenges that marketers face in adopting social networks as platforms for their online stores [80]. Because online customers have additional means they can use to detect fake marketers' claims. [81]. The desire for authenticity has recently increased in conjunction with the improvement of the standard of living and income of many customers [82]. Field evidence confirms that customers are increasingly looking for authenticity in products and brands that achieve their satisfaction and give them happiness in a world full of alternatives and diverse marketing offers [78]. Currently, authenticity ranks high in concerns as a criterion for many customers' purchase decisions. Honestly, authenticity trumps quality, just like quality has outperformed cost in previous periods [83], [84].

Although there is no agreement among marketing researchers on a comprehensive definition of the term authenticity [85]. At the beginning of its use, the term's focus was on the aspect of assuring customers that the products advertised were genuine. Then the knowledge connotations involved in the modern use of the term authenticity expanded to go beyond that narrow view, to include those values that confirm everything that is consistent, sincere, and authentic in the product [64], [86]. Certainly, marketers' keenness to adhere to authenticity in the credibility of advertising through their stores on social networks will inevitably enhance customer confidence and gives the product a unique position compared to other products in the market [71], contributes to a positive impact on their purchase intentions [87], Develop relationships with customers [88], Improving marketing performance under competitive markets [89]. Hence, the third hypothesis is as follows:

H1-2: Authenticity in advertising credibility has a positive impact on purchase intentions among Facebook users.

\section{3) Affirmation}

Affirmation represents the third dimension in advertising credibility, the truth from the perspective of many customers' stems from the consensus and affirmation of others from friends and relatives towards a certain thing or situation [64]. The experiences of other customers are a compass that can help the customer choose the best product [90]. Affirmation is a crucial dimension for marketers with the presence of social media networks that have facilitated access to and benefit from the experiences of others [91]. Inevitably, the nature of the communication systems in these networks is completely different from the communication systems in the traditional channels that used to rely on unilateral communications [92], [93]. More precisely, social networks have enabled customers to express opinions and discussions, and thus those opinions and discussions can make their way to reach a wide range of other customers [55], [94].

According to [89] customers who use social networks are more likely to rely on affirmations and discussions that take place on those networks. While [95] explained that the Internet environment includes some ambiguity or limited knowledge about the real parties behind the advertising messages, and here the affirmation of other customers plays an important role in removing the customer's doubts about advertising content. [96], [97] pointed out that other customers' affirmations on Facebook are an effective factor in influencing purchase intentions. Furthermore, the results of studies [98]-[101] revealed that positive comments, opinions, recommendations, or reviews on Facebook have an impact on purchase intentions. Therefore, the fourth hypothesis is:

\section{H1-3: Affirmation in advertising credibility has a positive impact on purchase intentions among Facebook users.}

Fig. 1 illustrates The Conceptual Model for the study. The independent variables in this study are ads credibility (trust, authenticity, affirmation). The dependent variable of this study is purchase intention.

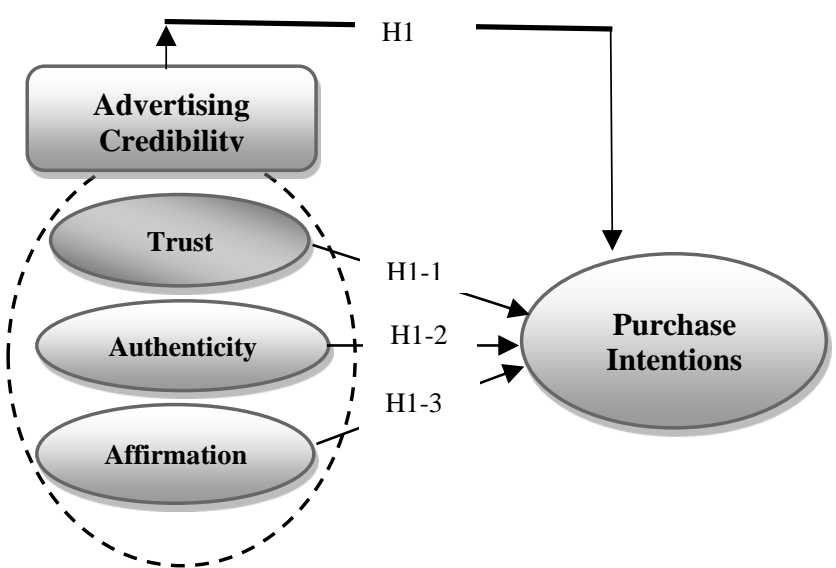

Fig. 1. The Conceptual Model.

\section{MYTHOLOGY}

\section{A. Study Design}

This study adopted the quantitative research method in addressing one of the most important challenges facing marketers in the current business environment, which is ad 
credibility. Many marketers today rely on social media platforms, especially Facebook, to post their ads about the products and services they are promoting. Due to a large number of ads and the widespread, as well as and the difference of customers throughout the covered area via the Internet, and the spacing between marketers and customers. Questions arise about the ads' credibility in social media and the extent of their impact on the purchasing intent of customers, which may limit the interaction with the ads and make them lose their desired effect. Therefore, the study sought to examine the impact of advertising credibility on purchase intention in the Iraqi business environment through the opinions of a wide range of customers who are users of the Facebook platform.

\section{B. Sampling}

Table I shows the personal characteristics of the members of the sample randomly selected from the academics, and students at the University of Basra, whose ages ranged between 20-40 years. The total number of questionnaire papers distributed was 579 , while the papers valid for analysis were only 487.

TABLE I: RESPONDENT PROFILE

\begin{tabular}{cccc}
\hline & Variables & Frequency & Percent \\
\hline \multirow{2}{*}{ Gender } & Male & 273 & $56 \%$ \\
& Female & 214 & $44 \%$ \\
\hline \multirow{2}{*}{ Age } & $20-25$ Years & 112 & $23 \%$ \\
& $26-30$ Years & 155 & $32 \%$ \\
& $31-40$ Years & 220 & $45 \%$ \\
\hline \multirow{2}{*}{ Education } & High School & 74 & $15 \%$ \\
Level & Certificate & 15 & $3 \%$ \\
& Diploma & 141 & $29 \%$ \\
& Bachelor's Degree & 213 & $44 \%$ \\
& Master's Degree & 42 & $9 \%$ \\
\hline
\end{tabular}

$\mathrm{n}=487$, Sources: Authors' survey.

\section{Data Collection}

The data collection tool in the current study consisted of two aspects. The first aspect included a number of questions related to the respondents' personal data, while the second aspect measured the study's two variables (advertising credibility, and purchase intentions) using the five-point Likert scale. Data collection extended for more than two months.

The current study used the previous literature to design and formulate the paragraphs of its questionnaire. The questions used to measure the credibility of the advertisement were from [80] [95]. While the questions used to measure purchase intentions were from [86].

\section{Data Analysis}

The current study employed a set of statistical techniques associated with the statistical program (SPSS) in analyzing and extracting the results.

\section{ANALYSIS AND FINDINGS}

\section{A. Reliability and Descriptive Analysis}

Usually, the first step in the statistical analysis begins with knowing the internal consistency between the paragraphs of the questionnaire by employing the Cornbrash's Alpha scale.
Table II reveals that the variables of advertising credibility and purchase intention have achieved coefficients higher than the recommended value of Cornbrash's Alpha scale (0.70) [102]. The trust driver scored the highest value $(0.920)$ and the lowest value recorded by the authenticity driver (0.813). The results showed that all extracted values of Cornbrash's Alpha scale have a high level of reliability.

Among the scales used to diagnose the extent of variance and dispersion in the answers of the study sample is the measure of central tendency. As shown in Table II. Trust achieved a mean (2.60), and the consistency was with a mean dispersion confirmed by the standard deviation value (0.872), this means that the answers were positive toward Trust. While authenticity got the lowest mean (2.55), the consistency was with an average dispersion confirmed by the value of the standard deviation (.973), which indicates that the answers were positive to some extent toward authenticity. Likewise, affirmation achieved a mean (2.71), and the consistency was with a mean dispersion confirmed by the standard deviation value (0.892), this means that the answers were positive toward affirmation. Whereas, purchase Intentions achieved a mean (2.78), and the consistency was with a mean dispersion confirmed by the standard deviation value $(0.926)$, this means that the answers were positive toward affirmation

TABLE II: RESULTS OF RELIABILITY TEST\& DESCRIPTIVE STATISTICS

\begin{tabular}{ccccc}
\hline \hline Variables & $\begin{array}{c}\text { Number } \\
\text { of items }\end{array}$ & $\begin{array}{c}\text { Cornbrash's } \\
\text { Alpha }\end{array}$ & Mean & $\begin{array}{c}\text { Standard } \\
\text { Deviation }\end{array}$ \\
\hline $\begin{array}{c}\text { Independent Variable: } \\
\text { Ad Credibility }\end{array}$ & & & & \\
\hline 1.Trust & 3 & 0.953 & 2.60 & 0.872 \\
2. Authenticity & 3 & 0.813 & 2.55 & 0.973 \\
3. Affirmation & 3 & 0.911 & 2.71 & 0.892 \\
Dependent Variable: & 4 & 0.859 & 2.78 & 0.926 \\
Purchase Intentions & & & &
\end{tabular}

Source: Survey Data.

\section{B. Correlation Analysis}

Table III shows the Pearson analysis that determines the nature of the correlation between the study variables. It is observed that there is a moderate positive relationship between trust driver and purchase intentions $\left(\mathrm{r}=0.285^{* *}, \mathrm{p}\right.$ $<0.01$ ), and that the authenticity driver has a weak positive relationship with purchase intentions $(r=0.187 * *, p<0.01)$, while it was affirmation driver and purchase intentions are moderately positive $\left(\mathrm{r}=0.334^{* *}, \mathrm{p}<0.01\right)$. This means that there is a positive relationship between advertising credibility and purchase intentions $\left(\mathrm{r}=0.443^{* *}, \mathrm{p}<0.01\right)$.

\begin{tabular}{cc} 
TABLE III: VALUES OF PERSON’S CORRELATION ANALYSIS \\
\hline Variables & Values \\
\hline Advertising Credibility & $0.443^{* *}$ \\
Trust & $0.285^{* *}$ \\
Authenticity & $0.187^{* *}$ \\
Affirmation & $0.334^{* *}$ \\
\hline
\end{tabular}

\section{Hypotheses Testing}

Table IV presents the results of testing the influence relationship between the study variables. The results of the regression analysis between the variables of trust and purchase intentions reveal an effect relationship $(\beta=0.303$, $\left.\mathrm{R}^{2}=12, \mathrm{~T}=11.909\right)$. This supports hypothesis (2). It was also found that the authenticity variable had a positive effect on purchase intention $\left(\beta=0.221, \mathrm{R}^{2}=9, \mathrm{~T}=9.145\right)$, which 
supports hypothesis (3). Regarding the relationship between the affirmation and purchase intention, there is a positive effect relationship $\left(\beta=0.376, \mathrm{R}^{2}=13, \mathrm{~T}=12.545\right)$, and this provides support for Hypothesis (4), it means that there is a positive influence relationship between the variables of advertising credibility and purchase intentions. The value of the total correlation coefficient for this relationship was $(\beta=$ $0.537)$, and the calculated $\mathrm{T}(15.427)$, which is greater than the tabulated $\mathrm{T}(3.315)$ at a significant level (0.01), and the advertising credibility was explained $(31 \%)$ of the change in purchase intentions, and this supports the validity of hypothesis (1).

\begin{tabular}{cccc}
\multicolumn{4}{c}{ TABLE IV: RESULTS OF REGRESSION ANALYSIS } \\
\hline Independent variables & $\beta$ & $\mathrm{R}^{2}$ & $\mathrm{~T}$ \\
\hline Advertising Credibility & 0.537 & 0.31 & 15.427 \\
Trust & 0.303 & 0.12 & 11.909 \\
Authenticity & 0.221 & 0.09 & 9.145 \\
Affirmation & 0.376 & 0.13 & 12.545 \\
Note. $\mathrm{p}<0.01,($ T tabulated $=3.315)$. & &
\end{tabular}

\section{CONCLUSION AND RECOMMENDS}

Credibility has always been a key dimension in the success of any business, but it has recently gained special importance in the field of online marketing and advertising, as it reflects the light that guides the customer in choosing the way he deals with the advertising messages and the truth of their content. Influencing customers in their virtual world within social networks is associated with marketers' efforts to design and broadcast advertising messages that include authentic and trusted content. In other words, marketers' efforts in advertising investment directed to create the desire or intent to buy will not succeed without seeking to create a clear image that enhances the customer's trust levels towards what he hears and sees from the marketing offers. Therefore, this study sought to shed light on the credibility of advertising and the main drivers that depend on it, and the extent to which that credibility affects the purchase intention of Iraqi customers who use the Facebook platform.

The study concluded that there is a moderate positive effect relationship between ad credibility and purchase intentions. Ad credibility drivers had varying effects on purchase intentions. The study showed that positive comments, opinions, recommendations, or reviews on Facebook have a significant positive effect on purchase intention among the respondents. Where many customers resort to verify ad credibility by taking advantage of the affirmations issued by friends and relatives as well as other customers on Facebook. The study also revealed moderate levels of trust in ad credibility and its impact on the intention to buy. Additionally, the authenticity drive had little effect on purchase intent. This means that customers have doubts about the credibility of some of the ads and marketing offers on the Facebook platform. In some cases, the skepticism may be due to the customer's knowledge of negative comments and feedback from other customers through their previous buying experiences. Not to mention the presence of an important factor that may reduce the desire of customers to buy online, which is the absence of laws and legislation that provide protection for them from Cheat and fraud that they may be exposed to by some marketers.
The study recommended that marketers should be aware of the importance of advertising credibility and its main drives that can contribute to reassuring customers about advertising messages and their content. In particular, trust, which is a vital variable in the success of a business in an environment such as the Internet, compared to the traditional purchasing method that allows the customer to see the specifications of the products directly before purchase. on this Point, advertisements related to new products and brands should focus on providing factual and truthful information for customer skepticism. Surely, hiding some information or exaggerating the specifications of the product would weaken the effectiveness of the advertisement and may lead customers to be indifferent towards the content of those advertisements. Furthermore, the advertising message must provide a sufficient guarantee to customers regarding the authenticity of the products promoted, such that this guarantee reflects the presence of a real person or entity behind the advertisement, and it is important for marketers to strive through their stores on Facebook to build an experience that best responds to customer requirements. There is no doubt that this will contribute to generating a good reputation for marketers that customers share with their friends and relatives on social media networks

\section{REFERENCES}

[1] N. Onyinye, K. Terna and N. Ogedi, "Awareness and use of social media in Advertising: The Case of Facebook among Residents of Port Harcourt, Nigeria", An International Multidisciplinary Journal, Ethiopia, Vol. 7 (4), No. 31, pp. 174-194, 2013.

[2] Q. Qing, and T. Oyedeji, "Credibility Perceptions of Different Types of Weblogs among Young Adults", Global Media Journal, Vol. 11, Issue 19, pp. 1-14, 2011.

[3] D. Lee, K. Hosanagar, and H. Nair, "Advertising Content and Consumer Engagement on social media: Evidence from Facebook", Management Science, vol. 64(11), 2018.

[4] C. Dakouan, R. Benabdelouahed, and H. Anabir, "Inbound Marketing vs. Outbound Marketing: Independent or Complementary Strategies", Expert Journal of Marketing, Vol. 7, Issue 1, pp. 1-6, 2019.

[5] Ishaverma, "Advertising Credibility: A Review of Literature. International Interdisciplinary Research Journal, Vol. 2 (1), pp. 189199, 2014.

[6] S. Choi, and N. Rifon, "Antecedents and Consequences of Web Advertising Credibility: A Study of Consumer Response to Banner Ads", Journal of Interactive Advertising, Vol. 3, No 1, pp. 12-24, 2002.

[7] L. Vilcekova, "Advertising Credibility Across Different Media Channels", International E-Journal of Advances in Social Sciences, Vol. 2, Issue 4, pp. 126-129, 2016.

[8] A. Mohammed, and M. Alkubise, "How do Online Advertisements Affects Consumer Purchasing Intention: Empirical Evidence from a Developing Country", European Journal of Business and Management, Vol. 4, No. 7, pp. 208-218, 2018.

[9] R. Indu, \& V. Raj "Developing a Theoretical Framework for a Study on the Impact of Advertising Credibility of Consumer Healthcare Products" European Journal of Commerce and Management Research, Vol. I, Issue 1, pp. 14-24, 2012.

[10] M. Nieuwenhuis, "The effects of website credibility on perceived advertisement credibility", Bachelor thesis, University of Twente, 2020.

[11] P. Liu and D. Poon, "A Hong Kong study of advertising credibility Journal of Consumer Marketing", vol. 26 (5), pp. 320-329, 2009.

[12] A. Yaakop, M. Anuar, and K. Omar, "Like It or Not: Issue of Credibility in Facebook Advertising. Asian Social Science", Vol. 9, No. 3, pp. 154-163, 2013.

[13] M. Malkanthie and S. Lanka, "Customer Attitude towards Mobile Advertising. Academy for Global Business Advancement (AGBA)", 15th World Congress, Thailand, 2018.

[14] Y. Fern, T. Ling, and L. Boon, "Mobile Advertising: Behavioura Intention among Undergraduates in Malaysia”, International Journal of Engineering \& Technology, 7, pp. 232-237, 2018. 
[15] S. Huq, S. Alam, and M. Nekmahmud, "Customer's Attitude towards Mobile Advertising in Bangladesh. International Journal of Business and Economics Research, vol. 4(6), pp. 281-292, 2015.

[16] M. Sheeraz, A. Khattak, and S. Mahmood, "Mediation of Attitude toward Brand in the Relationship between Service Brand Credibility and Purchase Intentions", Pakistan Journal of Commerce and Social Sciences, Vol. 10 (1), pp. 149-163, 2016.

[17] R. Bell, L. Mieth, and A. Buchner "Source memory for advertisements: The role of advertising message credibility", Memory \& Cognition, vol 49, pp. 32-45, 2021.

[18] N.V. Nielsen, "Global Trust in Advertising: Winning Strategies for an Evolving Media Landscape", 2015. https://www.nielsen.com/wp content/uploads/sites/3/2019/04/global-trust-in-advertising-reportsept-2015-1.pdf.

[19] K. Kumar, "Credibility of Health Care Advertising-An Empirical Understanding of its Multi-Dimensional Structure and Scale Validation with Special Reference to Children's Health Food Drinks", Indian Journal of Public Health Research \& Development, Vol. 11, No 1, pp. 374-379, 2020.

[20] A. Fanoberova and A. Kuckowska, "Effects of source credibility and information quality on attitudes and purchase intentions of apparel products- A quantitative study of online shopping among consumers in Sweden", Master thesis, Umea School of Business and Economics, 2016.

[21] M. Rebelo, "Dissertation Written Under the Supervision of Professor Carolina Afonso Dissertation. Master Thesis, The University Catolica Portuguesa, 2017.

[22] B. Hilligoss and R. Yung, "Developing a unifying framework of credibility assessment: Construct, heuristics, and interaction in context", Information Processing and Management, vol. 44, pp. $1467-$ 1484, 2008.

[23] A. Fanoberova, and A. Kuckowska, "Effects of source credibility and information quality on attitudes and purchase intentions of apparel products- A quantitative study of online shopping among consumers in Sweden",.Master thesis, Umea School of Business and Economics, 2016.

[24] T. Dinh, and B. Nguyen, "Attitudes toward Mobile Advertising: A Study of Mobile Web Display and Mobile App Display Advertising", Asian Academy of Management Journal, Vol. 19, No. 2, pp. 87-103, 2014.

[25] S. Unal, A. Ercis, and E. Keser, "Attitudes towards Mobile Advertising - A Research to Determine the Differences between the Attitudes of Youth and Adults", Procedia Social and Behavioral Sciences, vol. 24, pp. 361-377, 2011.

[26] M. Botelho, "The Impact of Influencers in The Consumer's Purchase Intention: The Cosmetic Industry", Master thesis, University Institute of Lisbon, 2019.

[27] F. Bekoglu, and C. Onaylı, "Strategic Approach in Social Media Marketing and a Study on Successful Facebook Cases. European Scientific Journal March 2016 edition, vol. 12, No. 7, pp. 261-274, 2016.

[28] F. Ur Rehman, M. Ilyas, and T. Nawaz, "How Facebook Advertising Affects Buying Behavior of Young Consumers: The Moderating Role of Gender", Academic Research International, Vol. 5(4), pp. 395-404, 2014.

[29] C. Treadaway, and M. Smith, "Facebook Marketing", Wiley Publishing, Inc, 2010.

[30] W. Iblasi, D. Bader, and S. Al-Qreini, "The Impact of Social Media as a Marketing Tool on Purchasing Decisions (Case Study on Samsung for Electrical Home Appliances)", International Journal of Managerial Studies and Research, Vol 4, Issue 1, pp. 14-28, 2016.

[31] D. Adilova, "Toward Understanding Social Media Marketing's Positives and Negative Sides from Literature Review Perspective", Journal of Business and Management, Vol. 19, Issue 2, pp. 67-74, 2017.

[32] F. Ferreira, and B. Barbosa, “Consumers' attitude toward Facebook advertising", Int. J. Electronic Marketing and Retailing, Vol. 8, No. 1, pp. $45-57,2017$.

[33] S. Rahman, "Tourism Destination Marketing Using Facebook as a Promotional Tool. Journal of Humanities and Social Science", Vol. 22, Issue 2, pp. 87-90, 2017.

[34] H. Soh, "Measuring Trust in Advertising: Development and Validation of the Adtrust Scale", PhD thesis, Athens, Georgia, 2006.

[35] R. Stokes, "eMarketing: The essential guide to marketing in a digital world", Sixth ed, Red \& Yellow, 2017.

[36] A. Vahl, J. Haydon, and J. Zimmerman, "Facebook ${ }^{\circledR}$ Marketing Allin-One for Dummies", 3rd Edition, John Wiley \& Sons, Inc, 2014.

[37] R. Roberts, "Privacy and Perceptions: How Facebook Advertising Affects its Users", The Elon Journal of Undergraduate Research in Communications, Vol. 1, No. 1, pp. 24-34, 2010.
[38] P. Sorokowski, A. Sorokowska, and M. Kowal, "Reasons for Facebook Usage: Data from 46 Countries", Frontiers in Psychology, Vol. 11, pp. $1-8,2020$.

[39] K. Curran, S. Graham, and C. Temple, "Advertising on Facebook", International Journal of E-Business Development, Vol. 1, Iss. 1, pp. 26-33, 2011.

[40] S. Vinerean, "Importance of Strategic Social Media Marketing", Expert Journal of Marketing, Vol. 5, Issue 1, pp. 28-35, 2017.

[41] T. Susnjar, "A beginner's guide to Facebook Advertising”, 2017 https://kontra.agency/Kontra_A_beginners_guide_to_Facebook_Adve rtising.pdf.

[42] I. Ubozhenko, “Advertising on Facebook Business Manager. Bachelor Thesis, International Business, 2018.

[43] R. Yousif, "The Extent of Facebook Users' Interest in the Advertising Messages", International Journal of Marketing Studies, Vol. 4, No. 3, pp. $122-133,2012$

[44] S. Frolova, "The Role of Advertising in Promoting a Product", Master thesis, Centria University of Applied Sciences, 2014

[45] N. Grideanu, "Advertising Management", Review of General Management, Vol. 19, Issue 1, pp. 95-105, 2014.

[46] T. Qazi, "Impact of Facebook Advertisements on Purchase Intentions of Mobile Facebook Users: Investigating the Moderating Role of Brand Origin and Perceived Product Value", PhD Thesis, Tohoku University, Japan, 2018.

[47] R. Terkan, "Importance of Creative Advertising and Marketing According to University Students' Perspective", International Review of Management and Marketing, Vol. 4, No. 3, pp. 239-246, 2014.

[48] S. Sebastian, and M. Pandowo, "The Impact of Credibility, Informative, And Hedonic/Pleasure on Youth Consumers' Attitude towards Advertising: Study of Mobile Advertising", Journal EMBA, Vol. 4, No. 1, pp. 1077-1085, 2016.

[49] L. Lim and S. Yao, "Mobile Advertising: An Insight of Consumers' Attitude", Scholar Conference in Business, Marketing and Tourism at Citadines Uplands Kuching on 22-25 June, pp. 372-398, 2018.

[50] G. Nicolaas, "The Influence of Mobile Marketing on Consumer Attitude Study at Student of Sam Ratulangi University", Journal EMBA, Vol. 4, No. 1, pp. 1221-1228, 2016.

[51] S. MacKenzie, and R. Lutz, "An empirical examination of the structural antecedents of attitude toward the ad in an advertising pre-testing context", Journal of Marketing, vol. 53(1), pp. 48-65, 1989.

[52] T. Daugherty, S. Chu, S. and K. Logan, "Understanding Consumer Perceptions of Advertising: A Theoretical Framework of Attitude and Confidence", Conference: American Academy of Advertising: San Mateo, pp. 1-3, 2008.

[53] M. Esmaeilpour, and Z. Mohseni, "Effect of Customer Experiences on Consumer Purchase Intention”, Romanian Economic Journal, No. 73, pp. 19-38, 2019.

[54] P. Angkouw, and F. Rumokoy, F. "Analysis of Consumer Behavior on Purchase Intention of Counterfeit Shoes in Manado", Journal EMBA, Vol. 4, No. 1, pp. 1126-1136, 2016.

[55] M. Valdez, and A. Lopez, "Purchase intention of ethnic textiles: The mediating role of the attitude of Mexican middle-class consumers", Contaduria Administration, vol. 64 (3), pp. 1-22, 2019.

[56] A. Garcia, B. Saura, and C. Orejuela C. "Purchase intention and purchase behavior online: A cross-cultural approach", Heliyon 6, pp. 1-11, 2020.

[57] V. Morwitz, "Consumers' Purchase Intentions and their Behavior", Foundations and Trends in Marketing, Vol. 7, No. 3, pp. 1-19, 2012.

[58] S. Younus, F. Rasheed, and A. Zia, "Identifying the Factors Affecting Customer Purchase Intention", Global Journal of Management and Business Research: An Administration and Management, Vol. 15, Issue 2, pp. 9-13, 2015.

[59] H. Le, P. Nguyen, and H. Dinh, "Effects of Country of Origin and Product Features on Customer Purchase Intention: A Study of Imported Powder Milk", Academy of Marketing Studies Journal, Vol. 21, Number 1, pp. 1-19, 2017.

[60] P. Laksamana, "Impact of Social Media Marketing on Purchase Intention and Brand Loyalty: Evidence from Indonesia's Banking Industry", International Review of Management and Marketing, vol. 8(1), pp. 13-18, 2018.

[61] T. Jiradilok, S. Malisuwan, and N. Madan "The Impact of Customer Satisfaction on Online Purchasing: A Case Study Analysis in Thailand", Journal of Economics, Business and Management, Vol. 2 , No. 1, pp. 5-11, 2014

[62] R. Rajendran, and C. Arun, "A Conceptual Framework on the Influence of Authenticity in Advertising and Positive Electronic Word of Mouth on Custom Satisfaction", Academy of Marketing Studies Journal, Vol 24, Issue 3, pp. 1-10, 2020.

[63] S. Hussain, T. Melewar, and C. Priporas, "Examining the effects of advertising credibility on brand credibility, corporate credibility and 
corporate image: A qualitative approach", Qualitative Market Research, Vol. 23 No. 4, pp. 549-573, 2020.

[64] P. Blackshaw, "The Six Drivers of Brand Credibility", Marketing Management, pp. 51-54, 2008. https://slidelegend.com/queue/the-sixdrivers-of-brand-credibilityama_59d048fe1723dd43059fa 776.html.

[65] R. Verstraten, "The effect of advertising credibility: could it change consumers' attitude and purchase intentions", Master thesis, Erasmus University Rotterdam.

[66] S. Celebi, "The Importance of the Truth Effect and Source Credibility for New Advertising", Journal of Yasar University, vol. 4(13), pp. 1021-1045, 2017.

[67] N. Nielsen, "Global Trust in Advertising and Brand Messages", Nielsen Co., New York, USA, 2013.

[68] D. Aydin, "Trust in Ad Media", International Journal of Economics and Management Engineering, Vol. 7, No 5, pp. 1206-1210, 2013.

[69] I. Hahn, F. Scherer, and K. Basso, "Consumer Trust in and Emotional Response to Advertisements on Social Media and their Influence on Brand Evaluation", Brazilian Business Review, Vol. 13, No. 4, pp. 4971.

[70] V. Kumar, and P. Pradhan, P. "Trust Management Issues in SocialMedia Marketing", International Journal of Online Marketing, vol 5(3), pp. 47-64, 2015.

[71] A. Enehasse, and M. Saglam, "The Impact of Digital Media Advertising on Consumer Behavior Intention: The Moderating Role of Brand Trust", Journal of Marketing and Consumer Research, Vol. 68 pp. 22-32, 2020

[72] M. Irshad, M. Ahmad, and O. Malik, "Understanding consumers' trust in social media marketing environment", International Journal of Retail \& Distribution Management, Vol. 48, No. 11, pp. 1195-1212, 2020.

[73] C. Yee and R. Yazdanifard, "How Customer Perception Shape buying Online Decision", Global Journal of Management and Business Research, Vol. 14, Issue 2, pp. 13-20, 2014.

[74] A. Leeraphong, and A. Mardjo, "Trust and Risk in Purchase Intention through Online Social Network: A Focus Group Study of Facebook in Thailand", Journal of Economics, Business and Management, Vol. 1, No. 4, pp. 314-318, 2013.

[75] N. Toan, "The effects of trust on Facebook consumer purchase intention: An empirical study on avocado in Vietnam", Master thesis, Ghent University (Belgium), 2018.

[76] S. Rahi, M. Ghani, and F. Muhamad, "Inspecting the Role of Intention to Trust and Online Purchase in Developing Countries", Journal of Socialomics, 6:1, pp. 1-7, 2017.

[77] J. Wijoseno, and M. Ariyanti, "Perceived Factors Influencing Consumer Trust and Its Impact on Online Purchase Intention in Indonesia", International Journal of Science and Research, Vol 6 , Issue 8, pp. 961-968, 2017.

[78] H. Bloh, "Authenticity in Food Marketing: The Effects of Authentic Marketing on Consumer Evaluations", Master thesis, Wageningen University, 2017.

[79] S. Brown, R. Kozinets, and J. Sherry, "Teaching Old Brands New Tricks: Retro Branding and the Revival of Brand Meaning", Journal of Marketing, vol. 67 (July), pp. 19-33, 2003.

[80] V. Arya, H. Verma, and D. Sethi, "Brand Authenticity and Brand Attachment: How Online Communities Built on Social Networking Vehicles Moderate the Consumers", Brand Attachment. IIM Kozhikode Society \& Management Review, vol. 8(5), pp. 1-17, 2019.

[81] C. Wathen, and J. Burkell, "Factors Influencing Credibility on the Web", Journal of The American Society for Information Science and Technology, vol. 53(2), pp. 134-144, 2002.

[82] R. Roostika, "An Analysis of Local Product Authenticity and Customer Attachments", Advances in Economics, Business and Management Research, Vol. 115, pp. 437-442, 2020.

[83] J. Gilmore, and B. "Authenticity: What Consumers Really Want" Harvard Business School Press, Boston, MA, 2007.

[84] E. Vliet, "The effectiveness of authenticity in the advertising of food products with an unknown brand", Bachelor thesis, Wageningen University, 2016

[85] M. Bruhn, V. Schoenmuller, and D. Schafer, "Brand Authenticity: Towards a Deeper Understanding of Its Conceptualization and Measurement", Advances in Consumer Research, Vol. 40, pp. 567-576, 2012.

[86] M. Beverland, A. Lindgreen, and M. Vink, "Projecting authenticity through advertising: consumer judgments of advertisers' claims", Journal of Advertising, Vol. 37, Issue 1, pp. 5-15, 2008.

[87] N. Lisichkova, and Z. Othman, "The Impact of Influencers on Online Purchase Intent", Master thesis, Malardalen University, 2017.

[88] H. Oh, Prado, P. and F. Korelo, "The effect of brand authenticity on consumer-brand relationships", Journal of Product \& Brand Management, Vol. 28 No. 2, pp. 231-241, 2019.
[89] W. Ndasi, and E. Akcay, "Understanding Authenticity in Digital Cause-Related Advertising: Does Cause Involvement Moderate Intention to Purchase", Westminster Papers in Communication and Culture, vol. 15(1), pp. 103-122, 2020.

[90] M. Saeed, A. Farooq, and W. Kersten, "Sustainable product purchase: does information about product sustainability on social media affect purchase behavior", Asian Journal of Sustainability and Social Responsibility, 4:9, pp.1-18, 2019.

[91] M. Khwaja, S. Mahmood, and U. Zaman, "Examining the Effects of eWOM, Trust Inclination, and Information Adoption on Purchase Intentions in an Accelerated Digital Marketing Context", Journal of Information, vol. 11, pp. 1-12, 2020.

[92] Y. Dwivedi, E. Ismagilova, and J. Carlson, "Setting the Future of Digital and Social Media Marketing Research: Perspectives and Research Propositions". International Journal of Information Management, pp. 1-37, 2020.

[93] S. Tabassum, M. Khwaja, and U. Zaman, "Can Narrative Advertisement and eWOM Influence Generation $Z$ Purchase Intentions", Journal of Information, vol. 11(12), pp. 1-16, 2020.

[94] A. Sulthana and S. Vasantha, "Influence of Electronic Word of Mouth eWOM On Purchase Intention", International Journal of Scientific \& Technology Research, Vol. 8, Issue 10, pp. 1-5, 2019.

[95] P. Mena, D. Barbe, and S. Chan-Olmsted, "Misinformation on Instagram: The Impact of Trusted Endorsements on Message Credibility", Social Media \& Society, pp. 1-9, 2020.

[96] A. Saleem, and A. Ellahi, "Influence of Electronic Word of Mouth on Purchase Intention of Fashion Products on Social Networking Websites", Pakistan Journal of Commerce and Social Sciences, Vol. 11 (2), pp. 597-622, 2017.

[97] K. Rao and B. Rao, "Examining eWOM Credibility - Consumer Purchase Intention Relationship in Facebook: A Mediation Analysis", Indian Journal of Marketing, Vol. 49, Issue 8, pp. 7-22, 2020.

[98] T. Hui, "The Effect of Source Credibility on Consumers' Purchase Intention in Malaysia Online Community", Journal of Arts \& Social Sciences, Vol. 1, Issue 1, pp. 12-20, 2017.

[99] S. Kunja, and A. Gvrk, "Examining the effect of eWOM on the customer purchase intention through value co-creation (VCC) in social networking sites (SNSs): A study of select Facebook fan pages of smartphone brands in India", Management Research Review, Vol. 43 No. 3, pp. 245-269, 2018.

[100] X. Yan, A. Shah, and L. Zhai, "Impact of Mobile Electronic Word of Mouth (EWOM) on Consumers Purchase Intentions in the Fast-Causal Restaurant Industry in Indonesia", Proceedings of the 51st Hawaii International Conference on System Sciences, 2018 http://hdl.handle.net/10125/50367.

[101] T. Putra, and R. Kalvin, "How Electronic Word of Mount (E-Wom) Affects Purchase Intention with Brand Image as a Mediation Variable: Case of Xiaomi Smartphone in Student", Vol.15, pp.1-7, 2020.

[102] J. Hair, W. Black, and B. Babin, "Multivariate data analysis: A global perspective", Upper Saddle River: Prentice Hall, 2010. 